
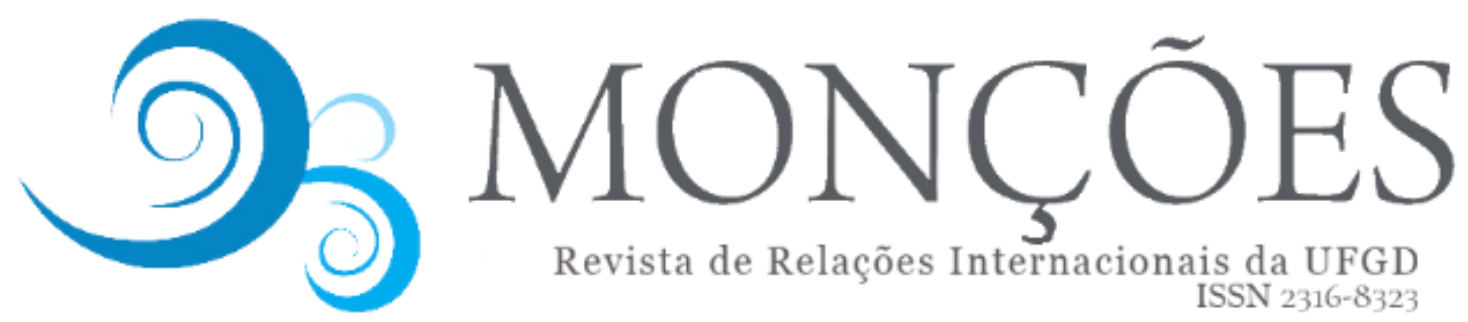

Revista de Relações Internacionais da UFGD

ISSN 2316-8323

\title{
A EXPANSÃO DAS MONOCULTURAS NA AMAZÔNIA: DO GLOBAL AO LOCAL, DA CHINA AO TIPNIS
}

\author{
BRUNA MURIEL HUERTAS FUSCALDO \\ Professora do Bacharelado em Humanidades e do Bacharelado em Relações Internacionais \\ da Universidade Federal do ABC, São Bernardo do Campo (SP), Brasil \\ ORCID: https://orcid.org/0000-0002-2679-7850 \\ bruna.muriel.ufabc@gmail.com
}

\begin{abstract}
Resumo: $O$ artigo trata dos impactos socioambientais causados pelas atividades extrativistas realizadas em territórios indígenas e biodiversos da América do Sul entre 2000 e 2015, no contexto do incremento das exportações de recursos naturais dos países da região para a China, em ascensão econômica no mesmo período. A aposta no extrativismo como eixo dos programas nacionais e regionais de desenvolvimento econômico e social por parte dos governos progressistas resultou em um cenário de conflito com as organizações indígenas, que lutam pelo controle de seus territórios, modos de vida e saberes. O embate em torno da construção da estrada que atravessa o Território Indígena e Parque Nacional Isiboro Sécure (Tipnis), na Amazônia Sul boliviana, sintetiza essa tensão, expondo os diferentes projetos civilizatórios em disputa na América do Sul como um todo, e na região Amazônica em particular. De um lado, o projeto viário expõe o avanço de diferentes monoculturas sobre a floresta e os seus povos. De outro, revela a luta dos indígenas das terras baixas bolivianas que resistem à consolidação da estrada na zona central do parque e, de forma mais ampla, ao estabelecimento do progresso como projeto social único e universal de todas as nações e povos, da China ao Tipnis.
\end{abstract}

Palavras-chaves: China, Extrativismo, Tipnis

\section{THE EXPANSION OF MONOCULTURES IN AMAZONIA: FROM THE GLOBAL TO LOCAL LEVEL, FROM CHINA TO THE TIPNIS}

\begin{abstract}
The paper highlights the socio-environmental impacts caused by extractive activities carried out in indigenous and biodiverse territories in South America between 2000 and 2015, in the context of the increase in exports of natural resources from countries in the region for China, in economic growth in the same period. During this period, several countries in the region faced a series of conflicts between progressive governments, which implemented national and regional economic and social development programs based on extractivism, and indigenous organizations, fighting to maintain control over their territories and ways of life. The conflict around the construction of the road that crosses the Indigenous Territory and Isiboro Sécure National Park, in the southern Bolivian Amazon, synthesizes this tension by exposing the different civilizing projects in dispute in the Amazon region. On the one hand, it exposes the advance, over the forest and its peoples, of monocultures that structure the paradigm of western capitalist and colonial modernity (in addition to the soy monoculture). On the other hand, it reveals the struggle of lowland indigenous people who, anchored in the Buen Vivir / Vivir Bien concept and in the Rights of Mother Earth, resist against the consolidation of the road in the central area of the park and, more broadly, the establishment of progress as an inevitable and universal social path for all peoples and nations, from China to Tipnis. La expansión de las monoculturas en la Amazonía: de lo global hasta lo local, desde China hasta Tipnis
\end{abstract}

Keywords: China, Extractive activities, Tipnis 


\section{LA EXPANSIÓN DE LAS MONOCULTURAS EN LA AMAZONÍA: DE LO GLOBAL HASTA LO LOCAL, DESDE CHINA HASTA TIPNIS}

Resumen: El artículo aborda los impactos socioambientales en territorios indígenas y biodiversos de América del Sur provocados por el extractivismo entre 2000 y 2015, en el contexto de incremento de las exportaciones de recursos naturales desde los países de la región hacia China, en expansión económica durante el mismo período.La apuesta de los gobiernos progresistas por el extractivismo como eje de los programas nacionales y regionales de desarrollo resultó en un escenario de conflicto con distintas organizaciones indígenas, que luchan por el control de sus territorios, formas de vida y saberes. El conflicto acerca de la construcción de la carretera que cruza el Território Indígena y Parque Nacional Isiboro Sécure (Tipnis), en la Amazonía Sur boliviana, refleja esta tensión, exponiendo los diferentes proyectos civilizatorios en disputa en América del Sur en su conjunto, y en la región amazónica en particular.Por un lado, el proyecto de la carretera expone el avance de diferentes monoculturas sobre la floresta y sus habitantes. Por otro lado, revela la lucha de los indígenas de las tierras bajas bolivianas que resisten contra la consolidación de la vía en la zona central del parque y, más ampliamente, el establecimiento del progreso como un proyecto social único y universal para todas las naciones y pueblos, desde China hasta Tipnis.

Palavras-claves: China, Neoextractivismo, Tipnis.

\section{Introdução}

O artigo faz uma análise dos impactos socioambientais em territórios biodiversos e indígenas advindos das atividades extrativistas que orientaram os programas de desenvolvimento dos governos progressistas sul-americanos, entre 2000 e 2015. No contexto, portanto, do vertiginoso crescimento econômico vivenciado pela China e o subsequente aumento de sua demanda por commodities.

O incremento das relações comerciais entre a China e os países sulamericanos na primeira década e meia do século XXI está relacionado ao programa de desenvolvimento singular aplicado no país asiático a partir das décadas de 1980 e, em especial, 1990, que articula intensas políticas de mercado sob o direcionamento de um Estado vigoroso. Como resultado, a China cresceu em média 10\% ao ano. Alcançou a posição de segunda maior economia do mundo, ultrapassando o Japão e atrás apenas dos Estados Unidos e, hoje, responde por 16,5\% do Produto Interno Bruto (PIB) mundial (ROCHA e BIELSCHOWSKY, 2018).

Do lado de cá do Oceano Pacífico, líderes que haviam percorrido uma trajetória intelectual de esquerda e/ou que vinham de movimentos sociais e populares diversos venceram as eleições presidenciais em distintos países da América do Sul. Com particularidades internas, os novos presidentes adotaram políticas de inclusão social com vistas a garantir crescimento econômico com maior distribuição social. 
Somente entre 1999 e 2010 foram eleitos Hugo Chávez Frías, na Venezuela; Luís Inácio Lula da Silva, no Brasil; Néstor e Cristina Kirchner, na Argentina; Tabaré Vázquez, no Uruguai; Fernando Lugo, no Paraguai; e José Mujica, novamente no Uruguai. Na Bolívia, a vitória de Evo Morales pelo Movimiento al Socialismo-Instrumento Político por la Soberanía de los Pueblos/MAS-IPSP, em 2005, resultou de alianças estratégicas entre organizações tradicionais de esquerda e movimentos indígenas e camponeses, no contexto de intensas manifestações sociais contra as políticas neoliberais implementadas no país na década anterior. No Equador, um processo similar culminou na vitória, em 2006, de Rafael Correa pelo Alianza País.

Nos dois países andinos novos processos constituintes foram abertos, do qual fizeram parte organizações populares diversas, com destaque para as indígenas, que participaram como sujeitos políticos com voz ativa no processo de construção de uma nova contratualidade social, orientada pela oficialização da plurinacionalidade. A proposta inovadora de organização político-burocrática dos Estados desafia a concepção hegemônica de Estado-nação, que em sua versão liberal clássica implica a homogeneização dos sujeitos como indivíduos livres e em sua versão multicultural acata as diferenças, desde que não se rompa com o marco político-econômico hegemônico. Desde uma perspectiva intercultural $e$, portanto, não hierárquica (WALSH, 2009), a plurinacionalidade prevê o reconhecimento das densidades sociais e culturais de forma horizontalizada e não homogeneizada, sob um projeto único de Estado e a partir de um viés crítico a modernidade capitalista (LINERA, 2004; SCHAVELZON, 2013; SORUCO, 2011).

Como resultado, as cartas constitucionais aprovadas em 2008, no Equador e em 2009, na Bolívia, estabeleceram o Vivir Bien (Suma Qamaña, em aimará) ou Buen Vivir (Sumak Kawsay, em quéchua ${ }^{1}$ ) como o novo projeto político-civilizatório que, crítico aos paradigmas hegemônicos do desenvolvimento e do progresso, deveria orientar as políticas públicas dos Estados Plurinacionais. Reconhecendo os saberes e as práticas sociais indígenas como fundamento da construção de um novo modelo social, igualitário e não depredatório, o Vivir Bien/Buen Vivir ganhou visibilidade

\footnotetext{
${ }^{1}$ Em quéchua Sumak Kawsay "[...] sería la vida en plenitud. La vida en excelencia material y espiritual [...] la armonía, en el equilibrio interno y externo de una comunidad" (MACAS, 2010, p.14). Apesar das similaridades, os significados dos termos mudam a depender do idioma ou, ainda, da variação do quéchua ou do aimará utilizada.
} 
mundial como uma proposta alternativa à crise social e ambiental contemporânea, inspirada em matrizes ancestrais andinas, plural e em constante construção.

Articulados à positivação do Vivir Bien/Buen Vivir, outros princípios, conceitos e direitos foram introduzidos nas constituições e nas legislações dos Estados Plurinacionais. É o caso dos Direitos da Natureza, Mãe Terra ou Pachamama ${ }^{2}$. A proposta legitimou a diversidade de interpretações ontológicas sobre a natureza existente nos territórios latino-americanos (SCHAVELZON, 2013), desafiando o direito ambiental clássico ao transformar a natureza no sujeito central da relação jurídica estabelecida. Anunciou, assim, a possibilidade de transição do sistema jurídico antropocêntrico para o biocêntrico. (ACOSTA e MARTíNEZ, 2011).

Apesar das inovações da normativa plurinacional, contudo, os governos do MAS e do Alianza País deram um novo fôlego ao extrativismo como o eixo dos programas para o desenvolvimento nacional e regional. Opção similar foi realizada por outros governos progressistas sul-americanos, que eram os novos gestores de amplas terras férteis e de territórios biodiversos. Contribuiu para esse desenrolar o fato de a crescente demanda asiática por recursos naturais, capitaneada pela China, ter desembocado na alta dos preços das commodities no mercado internacional e no incremento da especulação financeira sobre esses produtos e sobre a terra.

\section{O horizonte social pós-extrativista e pós-abissal da normativa plurinacional}

No esforço de jogar novas luzes sobre os impactos socioambientais das atividades extrativistas realizadas durante os governos progressistas em territórios indígenas e biodiversos da América do Sul nos primeiros 15 anos do século XXI, no contexto da alta demanda chinesa por commodities, este trabalho propõe um movimento reflexivo que vai do global ao local e inclui diferentes atores, áreas do conhecimento e escalas geopolíticas e geoeconômicas. Ele está fundamentado em uma pesquisa bibliográfica e empírica ${ }^{3}$ que tem como base o referencial teórico-

\footnotetext{
${ }^{2}$ Os Direitos da Natureza conformam o artigo 71 da carta magna equatoriana de 2008. Adquiriram aplicabilidade na Bolívia com a promulgação da Lei n 071, de 2010, e da Lei n 300 (Marco da Mãe Terra e do Desenvolvimento Integral para o Vivir Bién), de 2012. Também teve importância a Declaração Universal dos Direitos da Mãe Terra (2012), aprovada durante a Conferência Mundial dos Povos sobre a Mudança Climática e os Direitos da Mãe Terra, realizada na cidade de Cochabamba, em 2010.

${ }^{3} \mathrm{O}$ trabalho de campo foi realizado em 2015, nas cidades de La Paz, Cochabamba e Santa Cruz e na região do Chapare e envolveu conversas e entrevistas qualitativas, abertas e semiestruturadas, com autoridades governamentais, funcionários de organizações não governamentais, representantes de
} 
metodológico das Epistemologias do Sul (SANTOS 2007; SANTOS e MENEZES, 2010) em que o "sul" não corresponde apenas ao conceito geográfico e geopolítico, mas a uma metáfora que abarca tanto o sofrimento causado pelo capitalismo e pelo colonialismo em escala global quanto aos processos de resistência que foram emergindo ao longo da história.

Com o objetivo de enfrentar essa herança histórica, as Epistemologias do Sul apostam na recuperação do conjunto de saberes e práticas sociais produzidas pelos povos do Sul Global desqualificadas, historicamente, pelas diferentes instituições sociais, pelo direito e pelo pensamento dominante. Como aquelas experiências produzidas pelos povos indígenas da América Latina. (SANTOS 2007; SANTOS e MENEZES, 2010).

É neste sentido que as Epistemologias do Sul são também compreendidas como um projeto intelectual e político orientado para a criação de novas estratégias de transformação social, cujo horizonte é a construção de uma sociedade pós-abissal. Esta, nos termos de Santos (2007, p.11), "envolve uma ruptura radical com as formas de pensamento e ação da modernidade ocidental" que permite "pensar a partir da perspectiva do outro lado da linha, precisamente porque ele é o domínio do impensável no Ocidente moderno". Segundo o autor, para que esta transformação ocorra, é preciso criar mecanismos sociais, políticos e jurídicos que, pautados em um pensamento pós-abissal, sejam suficientemente capazes de criar alternativas àquele conjunto de experiências hegemônicas (SANTOS 2007). As experiências sociais, políticas e jurídicas inovadoras que formam parte do constitucionalismo e da legislação plurinacional da Bolívia e do Equador podem ser compreendidos como exemplos destes mecanismos. Ao incluírem princípios e direitos como o Vivir Bien e os Direitos da Mãe Terra, revelam a sua aposta naquilo que Santos (2007) explica como a co-presença radical das experiências produzidas em ambos os lados da linha abissal. Desse modo, dão visibilidade e legitimidade às experiências indígenas, no âmbito de um projeto político, social, epistemológico de transformação social cujo horizonte é a construção de uma sociedade pós-abissal e pós-extrativista (FUSCALDO, 2015).

organizações sociais indígenas e intelectuais indígenas e não indígenas. Contou com o apoio institucional e financeiro da Capes e do Cnpq. Parte das entrevistas foram individuais e parte foram coletivas, realizadas no âmbito do programa de pesquisa e extensão Realidade latinoamericana/Unifesp.

251 
Tomando emprestado da geologia a noção de "abissal"- que remete às qualidades do abismo, do que está nas profundezas dos oceanos e da crosta terrestre -, e trazendo-a para uma inovadora leitura geopolítica, Santos (2007) entende a modernidade ocidental capitalista como marcada por uma cartografia abissal. Durante o período colonial, as linhas cartográficas, como o Tratado de Tordesilhas, separavam geograficamente o velho e o novo mundo e os dividiam de maneira abissal, diferenciando de maneira radical os acontecimentos que ocorriam no "lado de cá" da linha abissal, o lado das metrópoles coloniais, daqueles que ocorriam do "lado de lá" da linha abissal, os territórios coloniais da América Latina (SANTOS, 2007). No cerne dessa teoria, está o reconhecimento de que as linhas cartográficas abissais conformadas durante o período colonial não desapareceram, com o fim do colonialismo político, subsistindo estruturalmente nas relações sociais e no pensamento moderno ${ }^{4}$.

Santos (2007) explica que a cartografia abissal moderna é dual: simultaneamente epistemológica e jurídica. A ciência moderna tornou-se o único conhecimento legítimo e universalmente válido, enquanto os conhecimentos indígenas, entre outros oriundos dos povos do Sul Global, são considerados um conjunto de crenças supersticiosas. O direito, por sua vez, que dividia o lado metropolitano - no qual vigoravam as leis e os princípios modernos - do lado colonizado, o território sem lei, dos sub-humanos, segue subalternizando o lado de lá da linha, o lado dos povos do Sul Global. Hoje, portanto, uma cartografia abissal permanece fundamentando as relações políticas e culturais desiguais protagonizadas pelo Ocidente no interior do sistema mundial.

As linhas abissais, no entanto, não são fixas. São mutáveis e, como resultado da luta dos grupos oprimidos, deslocaram-se ao longo da história em diferentes momentos (SANTOS, 2007). Assim como as lutas anticoloniais evidenciaram o "deslocamento" das linhas nos séculos XIX e XX, o constitucionalismo

\footnotetext{
${ }^{4}$ A discussão se insere no âmbito da corrente de pensamento plural que se convencionou denominar pensamento pós-colonial, para o qual o colonialismo não é entendido apenas como uma política de Estado de ocupação estrangeira, se manifestando também como "colonialidade", uma série de hierarquias (políticas, sociais, étnico-raciais, epistêmicas, econômicas) que se perpetuam após os processos de independências na América Latina no século XIX e a descolonização da África e da Ásia em meados do século XX. Articulando as diferentes formas de dominação, tais hierarquias atravessam os espaços públicos e privados, as relações sociais, as mentalidades, as subjetividades, sendo compartilhadas tanto por aqueles que delas se beneficiam quanto por aqueles que sofrem as suas consequências (CASTRO-GÓMEZ e GROSFOGUEL, 2007; QUIJANO, 1991; SANTOS, 2010).
} 
transformador plurinacional da Bolívia e do Equador evidencia um novo momento de deslocamento, também descolonizador, porém agora como parte do segundo momento de descolonização, produto e produtor do giro decolonial (CASTRO-GÓMEZ e GROSFOGUEL, 2007).

Para além de orientar-se por um pensamento pós-abissal, a normativa intercultural andina também se alinha aos debates sobre o pós-extrativismo, ao prever a diminuição paulatina das atividades produtivas que impactam a natureza e a sua substituição por práticas produtivas sustentáveis, como a agroecologia e a utilização de energias renováveis. Conforme Gudynas (2009), a transição pós-extrativista prevê a saída do extrativismo predatório de grande escala - que não inclui os custos sociais e ambientais externalizados -, e a passagem para o extrativismo absolutamente indispensável - realizado sob rígidas normas sociais e ambientais.

É importante frisar que, com base em Gudynas (2009), parte-se aqui de uma compreensão ampla de extrativismo. A princípio, este é compreendido como um conjunto diversificado de estratégias para a produção de riqueza baseada na extração ou exploração - em grandes volumes e em alta intensidade - de produtos naturais diversos, majoritariamente comercializados através da exportação sem processamento ou minimamente processados. Além das atividades mais típicas, como a mineração e a extração de gás e petróleo, portanto, também são consideradas aquelas relacionadas ao extrativismo agrícola com base na monocultura de exportação. Esse modelo de produção agrícola prioriza o uso de maquinários, de agrotóxicos, de sementes transgênicas e é caracterizado por um baixo índice de processamento. É o modelo predominante na América do Sul e é com base nele que a produção de soja, por exemplo, vem se expandindo para regiões biodiversas.

Também são considerados como parte das atividades extrativistas os empreendimentos que dão suporte à tais atividades (GUDYNAS, 2009). É o caso das obras relacionadas à geração de energia, como a construção de grandes represas hidrelétricas, ou a criação de uma infraestrutura física que permita o transporte e o escoamento dos produtos explorados pelas atividades de mineração, da exploração de hidrocarbonetos e do modelo agrícola fundamentado na monocultura de exportação. Como a construção de hidrovias, portos e vias rodoviárias, de que é exemplo o projeto do complexo viário no Tipnis. 
Apesar das suas especificidades, o conflito no Tipnis é emblemático por expor os diferentes projetos civilizatórios em disputa na América do Sul como um todo, e na região Amazônica em particular. De um lado, encontra-se o extrativismo como base dos programas de desenvolvimento nacional e regional orientado pelo paradigma do progresso. De outro, estão as organizações indígenas que se amparam no Vivir Bien e nos Direitos da Mãe Terra como mecanismos conceituais, políticos e jurídicos estratégicos dos seus processos de luta e resistência contra o estabelecimento do progresso como horizonte civilizatório único e universal de todas as nações e povos, da China ao Tipnis.

\section{A demanda chinesa por recursos naturais e o neoextrativismo progressista}

Era de se supor que o país, com seus 9,6 milhões de quilômetros quadrados, contendo significativos estoques de combustíveis fósseis e de minerais metálicos, alto potencial hidrelétrico e vastas extensões de terras produtivas, a China possuísse reservas naturais relativamente suficientes para o abastecimento de sua população. Contudo, embora detenha $13 \%$ da provisão mundial de carvão, $10 \%$ das terras agrícolas, 8,5\% de ferro, 6,5\% da água doce, 4\% do cobre, $2 \%$ do petróleo e $2 \%$ do gás natural (ROCHA e BIELSCHOWSKY, 2018), esses recursos não são suficientes para atender às necessidades da sua população, que ultrapassou a marca dos 1,4 bilhões de habitantes no final de 2019 (THE PEOPLE'S REPUBLIC OF CHINA, 2020), correspondendo a 19\% da taxa mundial. Observa-se, assim, um cenário de escassez relativa de recursos naturais no país, mesmo diante de uma aparente abundância, que resulta de seu enorme contingente populacional e do seu expressivo crescimento econômico.

Mudanças sociais e culturais significativas ocorreram no país asiático como resultado desse processo. $O$ incremento do poder aquisitivo de parte da população chinesa resultou no êxodo rural e no deslocamento para as grandes cidades. Observou-se a ampliação da classe média, a intensa urbanização do país, o aumento do consumo de produtos diversificados e o crescimento da utilização de meios de transporte diversos (públicos e privados). A fabricação de produtos manufaturados para atender os distintos setores da economia nacional como as da construção, dos transportes e da alimentação, foi incrementada, na expectativa de responder ao novo padrão de vida e consumo, fortalecendo a produção industrial no país. 
Diante desse cenário, a China construiu cadeias mundiais de fornecedores de recursos naturais em grande escala, ampliando seu leque de parceiros comerciais. Ao lado dos Estados Unidos e de alguns países da União Europeia, tornou-se um dos maiores compradores de bens primários (e um dos maiores exportadores de manufaturados). Entre os países que passaram a exportar para a China, abastecendoa com seus recursos naturais, encontram-se diversos países da África, do Oriente Médio, da Comunidade de Estados Independentes/CEl e da América Latina, com destaque para os da América do Sul.

A situação de subordinação estrutural do capitalismo periférico e de pouca diversidade produtiva - que, conforme Frank (1972) e Furtado (1974), não favorece o acúmulo de capital - se manteve na nova conjuntura geopolítica e econômica, em que a China, um país do Sul político global, deslocou as economias centrais, tornando-se o primeiro ou o segundo parceiro comercial de vários países da região. A intensidade da comercialização entre sul-americanos e chineses pode ser observada nos dados expostos por Rocha e Bielschowsky (2018). Segundo os autores, entre 2000 e 2015, o valor das importações chinesas oriundas da região latino-americana passou de 5 milhões de dólares ao ano para 103 milhões, 70\% dos quais relacionados a petróleo, ferro, cobre e soja, majoritariamente oriundos de três países: Venezuela (38\%), Brasil (33\%) e Colômbia (21\%). Entre 2003 e 2015, o aumento das importações da China de produtos da América Latina foi de 42\% ao ano. Em 2015, o grau de dependência dos produtos latino-americanos já beirava os $60 \%$ nos casos do petróleo, do cobre e do ferro e, no caso da soja, $85 \%$. Nesse mesmo ano, $77 \%$ das importações chinesas foram provenientes do Brasil (ROCHA e BIELSCHOWSKY, 2018).

O cenário de reforço do caráter primário-exportador dos países sulamericanos - e, em alguns casos, de reprimarização das economias, como nos casos da Argentina e do Brasil, onde importantes parques industriais foram destruídos frustrou o projeto de transformação da matriz produtiva que, historicamente, fez parte dos programas para o desenvolvimento nacional e regional na região ${ }^{5}$. A "Agenda de

\footnotetext{
${ }^{5}$ Esses programas foram inspirados pelo pensamento crítico da economia política latino-americana que impulsionado pela criação da Cepal, em 1949, ficou reconhecido mundialmente por sua forma heterodoxa de abordar a questão do desenvolvimento, em oposição à ortodoxia da teoria econômica desenvolvida pelos países centrais. Esta última considerava a diferenciação entre as economias dos países subdesenvolvidos e desenvolvidos como distintas etapas do desenvolvimento econômico global, afirmando que a divisão internacional do trabalho no sistema capitalista internacional acabaria por distribuir os benefícios econômicos entre a população mundial. Não havendo a necessidade, portanto, dos países exportadores de produtos primários se industrializarem. Destacando as
} 
BRUNA M. H. FUSCALDO

Outubro" (o programa político-econômico construído pelo MAS em diálogo com as suas bases sociais) previa, entre outras coisas, a nacionalização e a industrialização dos hidrocarbonetos. Apesar dos esforços neste sentido ${ }^{6}$, o governo priorizou a abertura de novas áreas de exploração ante o investimento na indústria energética nacional.

Revelaram-se, naquele momento, as dinâmicas contraditórias do neoextrativismo progressista da América do Sul (Gudynas, 2009). Diferentemente do modelo extrativista assumido pelo projeto de Estado mínimo, nas décadas de 1980 e 1990, em que os recursos ficavam concentrados nas mãos das elites nacional e internacional e não se traduziam em benefícios para a população, sob o direcionamento dos governos progressistas, a atividade contou com o protagonismo e a presença ativa do Estado. O excedente foi destinado à criação de políticas e programas sociais diversos, com destaque para aqueles destinadas aos setores mais marginalizados (GUDYNAS, 2009).

Em todos os países dirigidos por governos progressistas foram implementadas políticas de saneamento, educação, saúde, de equidade de gênero e

desigualdades intrínsecas à polarização do comércio mundial entre o centro, produtor e exportador de produtos manufaturados, e a periferia, produtora e exportadora de bens primários, os teóricos da CEPAL explicaram como, ao passo que os países centrais se apropriam dos frutos do progresso técnico global, na periferia essa apropriação fica restrita a uma elite minoritária, que os utilizam a fim de manter sua condição privilegiada de exportadora. Tomando-se por base esses argumentos, foram realizadas estratégias para o desenvolvimento dos países da região com foco na industrialização substitutiva das importações. Posteriormente, os teóricos da dependência analisaram os limites das experiências de industrialização pela articulação entre as elites nacionais e internacionais, que criou novas relações de dependência entre os países centrais e os periféricos (FRANK, 1972; FURTADO, 1974).

\begin{abstract}
${ }^{6} \mathrm{Na}$ Bolívia, o debate em torno do aumento da procura mundial pelo lítio - mineral essencial para a produção industrial de dispositivos eletrônicos e baterias elétricas, cuja maior reserva encontra-se na Bolívia - é um reflexo dos desafios que as novas dinâmicas geopolíticas e geoeconômicas colocam para a região. Destaca-se a nacionalização e as iniciativas de industrializar o lítio para exportá-lo com maior valor agregado, intensificadas após 2015, esbarrou na forte resistência por parte dos países industrializados, com destaque para os Estados Unidos. Conforme Bruckmann (2018, p.5): "la visión estratégica de Estados Unidos, que establece que el acceso y gestión de recursos naturales es una 'cuestión de seguridad nacional' que garantiza 'la salud de su economía y de su población', ha sido capaz de articular una estrategia multidimensional de apropiación de recursos naturales a nivel global [...]" Alguns pesquisadores conferem a questão do lítio a responsabilidades pelos eventos ocorridos em 2019, quando Evo Morales foi forçado a renunciar ao cargo após a "sugestão" do alto comando militar, no contexto das turbulentas mobilizações sociais que se seguiram à denúncia de fraude eleitoral alegada pela oposição com o respaldo da Organização dos Estados Americanos (OEA). Episódios de perseguição e violência contra militantes e representantes do MAS, lideranças sindicais e indígenas fizeram parte do contexto da renúncia. A senadora Jeanine Áñez se autoproclamou presidente interina do país contando com o apoio das Forças Armadas, da Polícia e dos grupos religiosos cristãos e, no momento de finalização deste trabalho, Evo Morales encontrava-se exilado na Argentina.
\end{abstract}

256

Monções: Revista de Relações Internacionais da UFGD, Dourados, v.9, n.18, jul./dez.

Disponível em: http://ojs.ufgd.edu.br/index.php/moncoes

DOI 10.30612/rmufgd.v10i18.11990 
de redistribuição de renda, acompanhadas de reformas educativas e de programas de distribuição de bônus sociais (CEPAL, 2014a; PNUD, 2013). Na Bolívia, a efetivação de políticas públicas diversas melhorou substancialmente a vida da população marginalizada, que passou a ter acesso a serviços e bens materiais e imateriais inalcançáveis até então (FUSCALDO, 2015) ${ }^{7}$. A melhora das condições de vida, entretanto, não foi acompanhada pela diminuição dos impactos socioambientais em territórios indígenas e biodiversos, levando a mobilização de diversas entidades da sociedade civil, com destaque para as organizações indígenas e ecologistas.

Com um teor diferente da crítica "cepalina", o embate dessas organizações com os governos progressistas enfatizou o caráter predatório e desorganizador dos modos de vida comunitários das atividades extrativistas. Na Bolívia, a polêmica em torno do projeto viário Villa Tunari-San Ignacio de Moxo, que inclui a construção de uma estrada que atravessa o centro do Território Indígena e Parque Nacional Isiboro Sécure, o Tipnis, foi o ápice da tensão entre o governo do MAS e setores das organizações indígenas que haviam sido aliados no contexto da Assembleia Constituinte (SCHAVELZON, 2013).

\section{Os impactos socioambientais do extrativismo}

Ao adentrarem em biomas sul-americanos como a Amazônia, o Cerrado, o Chaco, o Pantanal, a Mata Atlântica, a Caatinga, entre outros, as atividades extrativistas causam múltiplos impactos socioambientais.

No que diz respeito às alterações ambientais, observa-se a degradação da atmosfera, dos solos e da água, assim como a extinção da fauna e da flora local. $O$ extrativismo agrícola, associado às grandes queimadas e ao desmatamento, é um importante emissor de gases de efeito estufa e, junto com a queima de combustíveis fósseis, está entre as maiores causas de alterações ambientais relacionadas às mudanças climáticas. Além disso, o uso intensivo de fertilizantes e pesticidas gera altos níveis de toxicidade do solo e das águas (FAO, 2016, 2018).Cerca de 47\% da

\footnotetext{
${ }^{7}$ Conforme consta em Fuscaldo (2015), estudos publicados pela Comissão Econômica para a América Latina e o Caribe (CEPAL, 2014) demonstram que, de 2004 a 2011, a Bolívia experimentou grande redução nos índices de pobreza extrema e indigência, que baixaram, respectivamente, de $63,9 \%$ e $34,7 \%$ da população em 2004 para $36,3 \%$ e 18,7\% em 2012. No Equador, essa redução foi de 48,3\% e $21,2 \%$ em 2004 para $35,3 \%$ e $13,8 \%$ em 2012. Por sua vez, as taxas do Índice de Desenvolvimento Humano (IDH) aumentaram. Entre 2005 e 2013, o IDH boliviano ascendeu de 0,663 para 0,667 e o equatoriano, 0,687 para 0,711 (PNUD, 2013).
} 
área terrestre disponível na América Latina e no Caribe são cobertos por florestas, "[...] making the region a major global reserve of agricultural land and forest space", enquanto os outros $37 \%$ são destinados às atividades agropecuárias (FAO, 2016, p. 5). Enquanto a América do Norte e a Europa evidenciam o aumento de florestas devido aos programas de reflorestamento e da conversão de áreas não produtivas em bosques, os países latino-americanos e caribenhos estão no topo da lista daqueles que mais desmatam ${ }^{8}$.

Como anunciado anteriormente, os empreendimentos de suporte à exploração dos produtos naturais são aqui compreendidos como parte das atividades extrativistas. A construção de hidrovias, estradas e represas em meio a matas e florestas altera o regime das águas, leva à extinção da vida aquática, provoca o desmatamento e a ocupação das áreas demarcadas como resultado de processos migratórios descontrolados. O ruído do maquinário, como parte da poluição sonora causada por estas obras, é capaz de matar as aves autóctones do bioma afetado (ACOSTA et al., 2019; SERNAP, 2004; FAO, 2018; GUDYNAS, 2009).

Frequentemente, as regiões biodiversas da América do Sul são, também, territórios indígenas, ribeirinhas, quilombolas, caiçaras, reconhecidos ou não, daí os impactos sociais das atividades extrativistas também serem abundantes. De acordo com a CEPAL (2014b), os povos indígenas correspondem a cerca de $8 \%$ da população latino-americana, o que equivale, em termos absolutos, a 45 milhões de pessoas, divididas em 836 povos. A maior parte vive em territórios especialmente ricos em "recursos" hídricos e madeireiros, jazidas de minérios e solos férteis e propícios para as atividades agropecuárias. Ao adentrarem os territórios indígenas, o extrativismo desencadeia conflitos agrários que resultam em violências físicas e simbólicas contra esses povos, submetidos sistematicamente a processos de desapropriação - através da expulsão ou da diminuição/fim das demarcações -, suicídios e assassinatos de lideranças (CEPAL, 2014b; CIMI, 2014).

\footnotetext{
${ }^{8}$ Entre 1990 e 2015, a superfície florestal passou de 51,3\% para 46,4\% em relação à superfície total da região (FAO, 2018), que até 2016 perdia cerca de 2 milhões de hectares de florestas a cada ano (FAO, 2016). Em 2010 o Brasil, que concentra $60 \%$ da floresta amazônica, assumiu o topo do ranking mundial de países com maior deterioração ambiental absoluta (PNUMA, 2010). Cerca de 19\% da floresta original já foi desmatada, o equivalente ao território do Chile. Apesar do estímulo às políticas de contenção do desmatamento na Amazônia durante os governos do Partido dos Trabalhadores (PT) e do fato de o mesmo ter alcançado o seu menor valor histórico em 2012, de lá para cá o desmatamento vem apresentando um crescimento paulatino.
} 
O discurso que sustenta tais atividades produtivas, causadoras de inúmeros impactos socioambientais, é a busca pelo progresso. Desde o VivirBien/BuenVivir, entende-se que a expansão do ideal do progresso como horizonte civilizatório único é resultado do processo histórico de distribuição do poder no sistema-mundo patriarcal/capitalista/colonial/moderno (GROSFOGUEL, 2010). Evidenciado pelas nações que lideraram a revolução industrial, o grande paradigma do progresso se consolidou como modelo social a ser seguido globalmente, tornandose o caminho gradativo que, por meio da permanente acumulação de bens materiais e tecnológicos, levaria à satisfação contínua das necessidades e aspirações humanas. No século $\mathrm{XX}$, ele foi articulado ao desenvolvimento como estratégia político-econômica dos governos das nações capitalistas com vista ao alcance dessa satisfação (FURTADO, 1974; ACOSTA, 2013).

O binômio desenvolvimento/subdesenvolvimento renovou a visão dicotômica do sistema internacional e fundamentou uma nova estrutura de dominação, tendo em seu encalço a imagem do "civilizado" versus a do "selvagem", a do "avançado" versus a do "atrasado", dando continuidade, portanto, à série de figurações dicotômicas construídas desde os primórdios da colonização (GROSFOGUEL, 2010).

No âmbito da disputa das potências econômicas diante da independência dos países asiáticos e africanos, que tinham como modelo, respectivamente, os Estados Unidos e a União Soviética, o desenvolvimento tornou-se o contraponto capitalista às promessas socialistas, tendo por horizonte, ambos, o alcance do progresso (FURTADO, 1974; ACOSTA, 2013). Daí Quijano (2005) afirmar que a hegemonia dessa versão de modernidade opera tanto no projeto civilizatório capitalista quanto no socialista, configurando-se um dos mecanismos mais poderosos de dominação da subjetividade.

A partir da segunda metade do século XX, políticas estatais articuladas aos programas elaborados por instituições financeiras internacionais para a superação do "atraso" serviram para justificar as sistemáticas intervenções políticas e econômicas nos países da América Latina. Dos golpes militares, nas décadas de 1960 e 1970, às políticas de cooperação internacional estabelecidas ao fim da Guerra Fria, na virada para a década de 1990, o objetivo oficial desses programas era assegurar às nações 
latino-americanas "pobres" a oportunidade de se tornarem "em vias de desenvolvimento" (ACOSTA, 2013; GROSFOGUEL, 2010).

Nos anos 1990, vários projetos de cooperação internacional para o desenvolvimento, instituídos pelos governos a partir da articulação com os centros de poder econômico, os organismos financeiros internacionais (como o Fundo Monetário Internacional e o Banco Mundial) e ONGs aliadas aos interesses destes atores foram realizados na América do Sul. Vários foram implementados no altiplano boliviano e equatoriano, com vistas à superação do "atraso" do modo de vida comunitário de aimarás e quéchuas (FUNDO INDÍGENA, 2005). Em grande medida, é da resistência a tais projetos, assentada nas propostas de valorização da economia comunitária e de reconstituição institucional dos ayllus (a estrutura social agrícola fundamental do modo de vida indígena dos Andes) que surgem as formas embrionárias do VivirBien/BuenVivir (SCHAVELZON, 2013; FUNDO INDÍGENA, 2005).

Décadas atrás, Celso Furtado já alertava para o "irrealismo" do "mito do progresso" (FURTADO, 1974, p. 7) que estava sendo "utilizado para projetar a economia mundial" (1974, p. 15). Para o economista, o padrão de consumo sem limites adotado nos países industrializados, fundamentado na lógica do crescimento econômico infinito e na ideia da natureza como provedora inesgotável de recursos, não poderia ser expandido a toda a população mundial: "[...] se tal acontecesse, a pressão sobre os recursos não renováveis e a poluição do meio ambiente seriam de tal ordem (...) que o sistema econômico mundial entraria em colapso". O alerta sobre a iminência deste colapso é retomado, hoje, pelo líder Yanomami Davi Kopenawa, quando alerta que o "povo da mercadoria" está "estragando a terra e o céu e que nunca vão poder recriar outros" (KOPENAWA e ALBERT, 2015, p.419).

\section{III. $O$ avanço das monoculturas sobre a floresta e os povos indígenas que nela} habitam: o caso da estrada no Tipnis

É como reação à imposição do futuro único e predeterminado do progresso que os indígenas do Tipnis vêm se mobilizando contra o projeto viário Villa Tunari-San Ignacio de Moxos desde seu anúncio, em 2006.

Localizado em uma área de transição entre a Cordilheira dos Andes e a Amazônia Sul boliviana, o Tipnis possui a dupla titulação de parque nacional e território indígena demarcado. É o território demarcado de mojeños trinitários, 
yuracarés e chimanes, que se organizam ao redor de 63 comunidades indígenas, distribuídas ao longo de 1.236.296 hectares de uma área extremamente biodiversa ${ }^{9}$. Segundo o Plano de Manejo do Serviço Nacional de Áreas Protegidas (SERNAP, 2004), cerca de 62\% da superfície do Território Indígena e Parque Nacional Isiboro Sécure correspondem a áreas de planície. Outros $29 \%$ são regiões de montanha e $8 \%$ são piemonte (faixa de transição entre um e outro relevo) (SERNAP, 2004).

O parque encontra-se situado na maior bacia hidrográfica existente no planeta, a amazônica, na sub-bacia do Mamoré. Conta com uma extensa rede de afluentes - principalmente os rios Isiboro, ao Sul, o Sécure, ao Norte, e o Ichoa, localizado na parte central - e, por situar-se em uma zona de transição entre os Andes e a Amazônia, apresenta uma variedade ampla de cobertura vegetal, flora e fauna. Elas estão divididas por três grandes "ecorregiões", cada qual contendo características geomorfológicas e geológicas específicas. A das Yungas se localiza na vertente oriental e nos vales interandinos; enquanto nas terras baixas estão as ecorregiões das savanas inundáveis e dos bosques do Sudoeste da Amazônia (SERNAP, 2004).

A área foi demarcada como parque nacional pelo Decreto-lei nº 07401/1965 como forma de proteção ambiental e possibilidade de refúgio de indígenas cujos modos de vida eram impactados negativamente pelo crescente processo migratório de camponeses e ex-mineiros que deixaram o altiplano andino e se instalaram na região do Chapare. Iniciado na década de 1950, esse processo de ocupação das terras baixas ficou conhecido como colonização, daí os camponeses que habitam essa área serem conhecidos como colonizadores. Para além dos grupos mojeños trinitários, os yuracarés e os chimanes, portanto, o parque é habitado pelos colonizadores que, em sua maioria, estão agrupados ao sul do parque, conhecida como o Polígono Sete. Por parte da população branca, os camponeses bolivianos podem ser percebidos como indígenas pelo fato de possuírem origens étnicas ancestrais quéchua e aymara. No Tipnis, contudo, a identidade indígena é construída em oposição aos colonizadores, que possuem formas de ocupação do território e de

\footnotetext{
${ }^{9}$ O Plano de Manejo de 2004 indica a presença de 602 espécies de plantas no parque, das quais 16 encontravam-se ameaçadas de extinção (entre elas orquídeas, palmeiras e o cedro). No que diz respeito à fauna, foram contabilizadas 858 espécies, dos quais 108 são mamíferos (que correspondem a 30\% das espécies existentes em território boliviano; 470 são aves; 39 são répteis e 53 são anfíbios). Além disso, foram encontradas 188 espécies de peixes cuja abundância "[...] revela la importancia de los recursos hidrobiológicos" (SENAP, 2004, p.17) do parque.
} 
organização produtiva diferentes daquela que predominam entre os yuracares, os chimanes e os mojeños trinitários. (MORAES, 2014; PAZ, 2012; SCHAVELZON, 2013).

O plano de construir uma estrada para conectar os departamentos bolivianos de Cochabamba e Beni existe desde a década de 1980. Foi retomado oficialmente no contexto de aprovação da Lei 347.721, de 22 de setembro de 2006, durante a primeira gestão de Evo Morales, apresentado como uma questão de "prioridad nacional y departamental" (ACOSTA et al., 2019, p. 9). A construção da estrada traz diversas preocupações, entre as quais se destacam: a falta de análises concretas sobre os seus impactos socioambientais; o fato de dividir o parque em dois, facilitando o acesso a uma região onde o controle e a proteção territorial e ambiental se dão pela sua difícil acessibilidade; o risco aos ecossistemas e habitats endógenos; a ampliação das possibilidades de exploração de petróleo e outros recursos energéticos e naturais nas zonas centrais do parque; e a expansão das atividades produtivas dos camponeses colonizadores, com destaque para a produção da folha de coca, que poderia acarretar maior presença do narcotráfico na região (ACOSTA et al., 2019; SERNAP, 2004; PAZ, 2012; MORAES, 2014; SCHAVELZON, 2013).

A depredação dos ecossistemas locais do Tipnis já é significativa. Entre os fatores responsáveis por isso estão a ampliação da fronteira agrícola e o uso extensivo da terra com a aplicação de agrotóxicos, assim como a extração de madeira e a pesca com dinamite (ACOSTA et al., 2019; PAZ, 2012; SERNAP, 2004). A pressão por conta da exploração ilegal de madeira e dos assentamentos ilegais de colonizadores ameaça uma área conhecida como Bosque de Chimanes "[...] donde también ejercen su territorialidad los pueblos Tsimane, Mojeño y Yuracaré" (ACOSTA et al., 2019, p.19). O desmatamento aumenta a um ritmo constante, principalmente nas cercanias dos trechos já construídos da estrada ${ }^{10}$.

Segundo informe da Comissão do Tribunal dos Direitos da Natureza, responsável por avaliar o caso Tipnis (Acosta et al, 2019), após a revisão dos

\footnotetext{
${ }^{10}$ Datos de 2018 demuestran que la tasa de pérdida de bosque en este polígono es ocho veces más alta que en el resto del TIPNIS y el doble que en toda la Amazonía boliviana (CURRENT BIOLOGY, 2018). A este ritmo, se predijo la deforestación del $64 \%$ (610.848 ha) del parque en 18 años si se construye la carretera y una pérdida forestal del $43 \%$ si no se controla la expansión colonizadora del "polígono siete" aunque no se construya la carretera (PIEB, 2012). La mancha de deforestación de esta zona amenaza dirigirse a la Zona Núcleo del TIPNIS, donde se concentran los mayores valores de biodiversidad (ACOSTA et al., 2019, p.19).
} 
BRUNA M. H. FUSCALDO

documentos oficiais: "[...] y habiendo preguntado al Gobierno del Estado Plurinacional de Bolivia sin recibir respuestas concretas" (p.13) o Tribunal dos Direitos da Natureza ${ }^{11}$ concluiu que o trecho II, que atravessa a região central do parque, "no cuenta con el Estudio de Impacto Ambiental (EIA) y Licencia Ambiental respectiva". Apesar disso, a sua construção seguia em andamento em janeiro de $2019^{12}$. O Serviço Nacional de Áreas Protegidas, órgão dependente do Ministério do Meio Ambiente, alerta para os perigos da construção do trecho II e afirma que os impactos da estrada no médio e longo prazo trariam consequências negativas "[...] más relevantes que eventuales benefícios económicos que puedan generarse a corto plazo" (SERNAP, 2004, p. 82).

Em grande medida, no Tipnis a polêmica em torno da construção da via gira em torno da participação ou não dos colonizadores do Polígono Sete nos referendos sobre a estrada e sobre outros projetos que impactam o parque. A substituição do termo Terra Comunitária de Origem (TCO), estabelecido em 1990, para Território Indígena Originário Camponês (Tioc), conforme consta na Constituição de 2009, está no cerne desta disputa. Como TCO o caráter de propriedade coletiva do território indígena era enfatizado, enquanto a passagem para Tioc reforçou a ideia de propriedade individual da terra ${ }^{13}$ e concedeu aos colonizadores faculdades e proteções similares àquelas anteriormente concedidas aos indígenas (tais como 0 direito à consulta prévia e informada e a participação nos benefícios da exploração dos recursos naturais não renováveis).

\footnotetext{
${ }^{11}$ O Tribunal é uma iniciativa de ativistas, intelectuais e organizações indígenas e ecologistas e a sua finalidade é a aplicação daquilo que foi estabelecido pela Declaração Universal dos Direitos da Mãe Terra (CÚPULA MUNDIAL DOS POVOS SOBRE MUDANÇAS CLIMÁTICAS, 2010).

${ }^{12}$ A maior parte dos documentos divide a estrada em três trechos principais: o trecho I conecta as localidades de Villa Tunari à Isinuta, ao sul, concluído em 2016; o trecho III conecta Monte Grande à Inusita, na zona central do parque, e o trecho III, que vai de San Ignacio de Moxos até Monte-Grande, ao norte. Os trechos III e II estavam parcialmente concluídos, sendo o último o mais polêmico por adentrar a região central do Tipnis, onde habita a maior parte das comunidades indígenas.

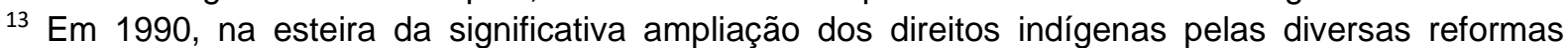
constitucionais multiculturais e da aprovação, no ano anterior, da Convenção 169 da OIT os três grupos indígenas no Tipnis protagonizam a Marcha pela Dignidade e pela Vida, que percorreu o país de Trinidad, na Amazônia, até La Paz, nos Andes. Entre outras coisas, os yuracares, os chimanes e os mojeños trinitários exigiam que o Estado reconhecesse o parque nacional como território indígena. Como resultado, o Tipnis foi reconhecido como Terra Comunitária de Origem (TCO), pelo Decreto Supremo 22.619, de 1990, garantindo assim o direito à propriedade coletiva (comunal). Também foi estabelecida a línea roja, linha demarcatória que, com o objetivo de evitar novos assentamentos de colonizadores, demarca o Polígono Sete, na área sul do parque. Em 2009, como dito, o termo foi substituído Tioc, definido pelos artigos 269, 290 e 298 da carta constitucional (BOLÍVIA, 2009) como áreas de produção, aproveitamento e conservação dos recursos naturais e, simultaneamente, espaços de reprodução social, espiritual e cultural das comunidades indígenas originárias e camponesas.
} 
Os colonizadores, que em sua ampla maioria são favoráveis à construção da estrada, conquistaram assim o direito de participar dos processos de consulta. Entre os argumentos encontrados tanto na literatura consultada (ACOSTA et al, 2019; MORAES, 2014; PAZ, 2012; SERNAP, 2014; SCHAVELZON, 2013) quanto nos depoimentos dos colonizadores e dos funcionários do governo, coletados in loco, estão o fato da estrada (1) aumentar as possibilidades de acesso às localidades afastadas, ainda mais urgente no período de cheias; (2) ampliar as possibilidades de acesso às estruturas de saneamento, educação e saúde; e (3) favorecer o transporte dos produtos agrícolas ali produzidos para outras regiões da Bolívia. É importante retomar que os colonizadores protagonizaram as mobilizações populares que levaram Evo Morales ao poder e, ao longo de sua gestão, e respaldaram o modelo de desenvolvimento do MAS para as terras baixas. Com destaque para os produtores da folha de coca ${ }^{14}$.

Em 2011, o setor opositor da Confederação dos Povos Indígenas da Bolívia (Cidob) encabeçou a VIII Marcha dos Indígenas das Terras Baixas contra a construção da estrada. A violenta reação da polícia chocou os movimentos indígenas de toda a América Latina, assim como a opinião pública nacional e internacional, quando fotos de indígenas presos, feridos e amordaçados estamparam as manchetes dos jornais. Segundo Emilio Noza, presidente da Subcentral Indígena do Sécure (Tipnis), que representa 22 comunidades indígenas margeadas pelo rio Sécure, ao norte do parque ${ }^{15}$, a manifestação foi, primeiro, bloqueada por camponeses aliados ao governo e, depois, violentamente reprimida pela polícia política, no que ficou

\footnotetext{
${ }^{14}$ Como parte do processo de êxodo dos camponeses do altiplano esteve a boa adaptação da folha de coca às condições climáticas das terras baixas, fazendo com que os colonizadores passassem cultivála em detrimento de outros produtos agrícolas. No plano legal, a coca serve para fins medicinais e para o acullico, o ato ancestral de mascar a folha de coca. No plano ilegal, parte do cultivo serve de matériaprima à cadeia produtiva internacional do narcotráfico. Na década de 1990, no escopo da luta internacional contra as drogas, a região do Chapare foi considerada área de comercialização conectada à rota internacional do narcotráfico. É, em grande medida, da resistência às políticas intervencionistas e violadoras dos direitos humanos conduzida pela Agência dos Estados Unidos para o Desenvolvimento Internacional/USAID, que tinham por objetivo eliminar a produção da folha de coca no Chapare, que desponta o movimento cocaleiro liderado por Evo Morales (PAZ, 2012; URQUIDI, 2007).

${ }^{15} \mathrm{Na}$ parte sul encontra-se a Subcentral do Tipnis, que representa as comunidades dos rios Isiboro e Ichoa.
} 
BRUNA M. H. FUSCALDO

conhecido como o Massacre da Chaparina. O episódio é lembrado como "[...] un recuerdo de mucho dolor que uno no puede olvidar jamás". ${ }^{16}$

Como forma de resistir à estrada, as organizações indígenas das terras baixas bolivianas exigem que se faça jus aos direitos indígenas e ambientais já amplamente reconhecidos ${ }^{17}$. Além disso, recorrem à Constituição e à legislação plurinacional, inovadoras por seu horizonte pós-abissal e pós-extrativista (FUSCALDO, 2015). Em maio de 2012, evidenciando a ampliação da articulação transnacional da luta indígena observada desde os anos 1990, no contexto da crescente atuação da sociedade civil global, 74 comunidades indígenas do Tipnis entraram com uma petição, apresentada à Comissão Interamericana de Direitos Humanos (Cidh), contra o Estado boliviano por violação dos seus direitos territoriais ${ }^{18}$.

Em 17 de agosto de 2017, a Coordenação das Organizações Indígenas da Bacia Amazônica/COICA publicou a Resolución Coica por la defensa del Tipnis (COICA, 2017). A organização representa mais de trezentos povos indígenas da Amazônia e é uma das mais atuantes no sistema político e jurídico internacional e global, atuando contra o extrativismo, a desaparição dos povos e as mudanças climáticas. Mais recentemente, em janeiro de 2019, uma das organizações que apoiaram a ação da CIDH, a Central de Povos Étnicos Mojenhos do Beni (Cpemb), se

\footnotetext{
${ }^{16}$ Entrevista pessoal realizada em 6 de julho de 2015, na sede da Cidob, em Santa Cruz de La Sierra (Bolívia). É importante destacar que a sede visitada foi a opositora a Evo Morales, a Cidob, que está na liderança das mobilizações contra a construção da estrada no Tipnis. Como outras organizações sociais bolivianas, estava dividida em dois setores, um opositor e outro favorável ao governo, possuindo duas sedes físicas, duas lideranças, etc.

${ }^{17}$ Tais como os direitos à autodeterminação e à consulta prévia nas situações em que projetos estatais ou internacionais impactem os territórios e o modo de vida das populações autóctones. Ambos estão previstos nas diversas constituições latino-americanas, na Convenção 169 da OIT (1989), tendo sido corroborados pela Declaração das Nações Unidas sobre os Direitos dos Povos Indígenas de 2007. Elas também apoiam suas lutas nos direitos ambientais clássicos, reconhecidos nas normativas nacionais e internacionais, como as constituições e a Declaração do Rio sobre o Meio Ambiente e o Desenvolvimento, aprovada pelas Nações Unidas durante a I Cúpula da Terra, em 1992.

${ }^{18} \mathrm{Em} 2015$, o anúncio do Decreto Supremo no 2.366, de 20 de maio autorizou a exploração de gás e petróleo em áreas de proteção ambiental e territórios indígenas, até então consideradas intangíveis.Desde a perspectiva governamental, a estrada seria a condição para o estabelecimento de políticas públicas de saúde e educação e integração geopolítica do país e as mobilizações dificultavam o processo do desenvolvimento social em andamento, encobrindo agendas político-partidárias da direita, aliada dos interesses estrangeiros na Bolívia (LINERA, 2015).No ápice do conflito, intensificaram-se o questionamento, o controle e as tentativas de encerrar as atividades de ONG ecologistas e ambientalistas por parte do governo boliviano. Entre os argumentos apresentados pelo MAS, um se destaca pela sua veracidade: o fato de que, antes da chegada do partido ao poder, certas organizações não governamentais intervinham na política e na economia do país atendendo os interesses políticos e econômicos dos Estados Unidos e das instituições financeiras internacionais. Essas intervenções contribuíram para o desmantelamento de políticas públicas e instituiram práticas de violência e desrespeito aos direitos humanos na região do Chapare.
} 
pronunciou exigindo maior rapidez na abertura do processo e o cancelamento imediato da construção da estrada (Cpemb, 2019 apud Cejis, 2020). Conforme Adolfo Suarez, diretor da organização indígena das terras baixas Cidob, o governo do MAS “[...] no aplica lo que está en la constitución (...). Entonces para que hemos hecho una nueva constitución?"9.

Observe-se, por exemplo, o artigo 313 da Constituição Plurinacional da Bolívia de 2009 que, alinhado ao princípio do Vivir Bien, transformou a economia comunitária indígena em uma das formas econômicas do Estado, obrigando a sua proteção e fomento. Legitimou, assim, a diversidade de experiências produtivas e lógicas temporais existentes no interior do território boliviano, ao mesmo tempo em que desafiou a hegemonia da lógica produtiva e temporal da modernidade capitalista. Além disso, a carta constitucional da Bolívia (2009, Art. 311 e 306) assegura que a economia plurinacional deve ser regida pelos princípios ancestrais da solidariedade, da reciprocidade e da complementaridade, intrinsecamente relacionados às lógicas da produção, distribuição e circulação material no interior das comunidades indígenas. Os três princípios estruturam a vida nos ayllus andinos (FUNDO INDíGENA, 2005), estando presentes também nas lógicas produtivas indígenas das terras baixas, amazônicas (DESCOLA, 2001; VIVEIROS DE CASTRO, 2002).

Apesar de relacionar-se ao enfrentamento local de indígenas e colonizadores, contudo, a polêmica em torno do projeto viário Villa Tunari-San Ignacio de Moxos não se restringe a ela. Tampouco se resume a um problema exclusivamente nacional, do tipo indígenas versus governo do MAS e camponeses. A construção da estrada na Amazônia sul boliviana articula-se às dinâmicas políticas e comerciais mais amplas, regionais e internacionais, evidenciando o avanço de diferentes monoculturas sobre a floresta e os povos que nela habitam: a monocultura da soja e as monoculturas estruturantes da modernidade ocidental capitalista e colonial (Santos, 2007).

III.a O avanço, sobre a floresta e seus povos, da monocultura da soja

Embora não esteja diretamente ligada às relações comerciais entre a Bolívia e a China, o projeto viário que atravessa o Tipnis responde às expectativas de escoamento das commodities pelo Oceano Pacífico, diante do aumento da demanda

${ }^{19}$ Entrevista pessoal realizada em 6 de julho de 2015, na sede da Cidob, em Santa Cruz de La Sierra, Bolívia. 
asiática. Neste sentido vincula-se a expansão do agressivo modelo agrícola da monocultura da soja.

Retome-se que o contexto analisado é aquele de afirmação de um novo momento do regionalismo na América do Sul, caracterizado pela crítica ao reducionismo do perfil pró-mercado das iniciativas para a integração regional das décadas anteriores e orientado tanto por uma perspectiva de integração atenta à centralidade do Estado na regulação econômica quanto pela necessidade de um desenvolvimento com equidade, voltado para a diminuição das assimetrias entre os países-membros.

Novas iniciativas foram impulsionadas, como a União de Nações SulAmericanas (Unasul) ${ }^{20}$ que previa, entre outras estratégias para o desenvolvimento da região, o investimento na construção de megaprojetos de infraestrutura voltada para a produção e exportação de commodities sul-americanas para o mercado internacional. A Iniciativa para a Integração da Infraestrutura Regional Sul-americana, IIRSA, foi criada nesse contexto. Entre os seus objetivos estava o de impulsionar a integração econômica regional por meio da construção de corredores transoceânicos que conectassem o Pacífico ao Atlântico, diante da intensificação das relações comerciais dos países sul-americanos com a Ásia e, em particular, da necessidade de escoar a soja brasileira para a China ${ }^{21}$.

Segundo o Atlas da Complexidade Econômica (2017), a soja e seus derivados representaram $36,39 \%$ do total de produtos brasileiros exportados para a China em 2015. Em sua maioria, o produto é utilizado na elaboração de ração para suínos e bovinos, importante no contexto das modificações culturais vivenciadas pelos chineses nas duas últimas décadas, entre as quais a cultura alimentar. A expansão da classe média urbana, anteriormente comentada, significou o aumento do consumo

\footnotetext{
${ }^{20}$ A Aliança Bolivariana para os Povos da Nossa América - Tratado de Comércio dos Povos (Alba) e a Comunidade dos Estados Latino-Americanos e Caribenhos (Celac) foram outras das iniciativas criadas no âmbito do novo regionalismo latino-americano. Naquele momento, diversas negociações comerciais entre a China e a região foram mediadas pelas novas entidades, como evidenciado pelo Fórum ChinaCelac, estabelecido em 2014 como uma plataforma para a cooperação econômica e política entre os países membros e os ministros de relações exteriores da China.

${ }^{21}$ Entre 2006 e 2012 foram realizados diversos procedimentos burocráticos relacionados ao desenho da obra, à aprovação de leis específicas e licenças ambientais e à concessão e ao financiamento do empreendimento. Em 2008, estabeleceu-se que a construtora brasileira OAS seria uma das maiores responsáveis pelo empreendimento, contando, para tanto, com o apoio financeiro do Brasil, através do BNDS. Em 2012 o acordo foi revogado e outras empresas, bolivianas e venezuelanas, assumiram o trabalho (ACOSTA et al., 2019).
} 
de carne pelos chineses, em particular a bovina, considerada uma iguaria até a década de 1990. Se em 1990 o consumo médio de carne por pessoa no país girava em torno de 37,7kg/ano, em 2007 esse número já havia subido para 79,9kg (FAO, 2007).

Hoje, embora a China seja autossuficiente na produção de carne, ainda é dependente de insumos destinados à alimentação dos animais, particularmente a soja, cuja produção em território chinês é limitada. Entre outros fatores, pelo parco acesso dos produtores rurais às tecnologias mais recentes (como aquela relacionada às sementes transgênicas), o predomínio do cultivo em pequena escala e, em especial e pelo fato da política nacional de segurança alimentar chinesa priorizar a produção de grãos diretamente voltados para a alimentação dos chineses, como o arroz. Esse contexto contribuiu para a crescente necessidade de importação do grão e seus subprodutos, que passou de 10 milhões de toneladas, em 1990, para 82 milhões, em 2015 (ROCHA e BIELSCHOWSKY, 2018).

Abramovay (2010) explica que uma agressiva expansão das atividades agropecuárias no Cerrado brasileiro foi observada na primeira década do século XXI (em parte pelo estímulo às políticas de contenção do desmatamento na Amazônia). Embora seja um dos biomas mais ricos do planeta, o Cerrado reduziu-se a uma fronteira agrícola pronta para ser desmatada e, apenas entre 2002 e 2008, a região foi devastada duas vezes mais que a região amazônica. Entre 2003 e 2015 foram registrados 754 casos assassinatos e 704 casos de suicídios entre os indígenas no Brasil. Mais da metade dos casos estavam concentrados no Estado do Mato Grosso do Sul e resultaram dos conflitos territoriais envolvendo os grupos étnicos Terena, Guaraní e Guaraní-Kaiowá e os fazendeiros ligados ao agronegócio, com destaque para aqueles que envolvem a abertura de novas fronteiras agrícolas para a expansão da produção de soja (CIMI, 2014).

O militante Oscar Oliveira (2011, p.1), que ficou conhecido pelo seu protagonismo durante o levante popular contra a privatização da água, na cidade de Cochabamba, em 2000, associa a estrada no Tipnis ao projeto mais amplo da IIRSA e aos interesses do Brasil, que estaria "[...] muito interessado numa estrada para transportar sua produção ao continente asiático, principalmente à China". A pesquisadora boliviana Sarela Paz aprofunda a questão: 
No es que el IIRSA ha imaginado la carretera del Tipnis. Cuando leen los documentos que están pensados desde UNASUR, no van encontrar la carretera del Tipnis. (...) Pero, si van encontrar la necesidad de construir una infraestructura, de vincularnos, asociarnos, hacer con que todos los ejes de la producción soyera tengan infraestructura. $Y$ no es que la soya va ingresar el Tipnis, porque los suelos no son para eso (...). Pero los soyeros si necesitan rutas más cortas y es más fácil de Rondonia llegar al Pacífico entrando por Bolivia que irse por el Atlántico (...). Entonces, pensando de esa perspectiva (...), para lo que es el IIRSA, esa carretera engrena. Tiene que ver con sus dinámicas. ¿Por qué? Porque efectivamente puede formar ramales que conectan Brasil al Pacífico. Los Estados que se están volviendo estados significativos en la producción de soya y que permiten acortar costos de producción, sobretodo en el tema de transporte. Brasil tiene mucho que ver con ese conflito. ${ }^{22}$

Uma visita à dimensão local do conflito na Amazônia sul-boliviana será realizada a seguir, como forma de examinar outras de suas nuances. Interessa, em particular, a leitura sobre os distintos modos de vida que coexistem no Tipnis (ao qual correspondem formas distintas de ocupação do território, de formas produtivas e de lógicas temporais).

III.b Saberes, formas produtivas e temporalidades indígenas

Como foi possível observar, no Tipnis identificam-se duas formas distintas de ocupação do território: a dos indígenas e a dos camponeses colonizadores. A estrada, como parte do projeto de desenvolvimento do MAS para as terras baixas, está sintonizada com as demandas desse último setor, lançando os primeiros para relações mercantis que não correspondem à sua lógica de produção comunitária (PAZ, 2012).

De um lado, estão as atividades produtivas dos camponeses colonizadores, marcadas pela monetarização, mercantilização e circulação de mão de obra. $O$ destino da sua produção são os mercados regionais e nacionais e, entre os diversos elementos que compõem o ecossistema local, prioriza-se a terra, considerada propriedade privada. Desse modo, o bosque é convertido em terra cultivável para a comercialização, o seu uso e aproveitamento são realizados individualmente e são altos os índices de desmatamento. Sob essa lógica, a estrada é funcional aos colonizadores porque favorece o transporte de seus produtos para outras regiões da Bolívia, aumentando o potencial mercantil de sua produção (MORAES, 2014; PAZ, 2012; SCHAVELZON, 2013).

\footnotetext{
${ }^{22}$ Entrevista coletiva realizada em 8 de julho de 2015, em Cochabamba, Bolívia.
} 
De outro lado, está a economia comunitária dos yuracarés, dos chimanes e dos mojeños trinitários, girando em torno da caça, da pesca, da agricultura e da coleta de alimentos. Afincada na produção de subsistência, responde às necessidades das famílias e não às demandas do mercado. Embora existam projetos que articulam tais atividades aos circuitos econômicos regionais, nacionais e internacionais (como a produção e a venda de chocolate ou o turismo ecológico), os projetos não rompem com a propriedade coletiva da terra, que caracteriza a economia étnica local e que é o eixo fundamental do controle político dos indígenas sobre o território (MORAES, 2014; PAZ, 2012; SCHAVELZON, 2013).

As atividades produtivas dos grupos indígenas não estão orientadas para o acúmulo, o lucro ou a exploração de mão de obra alheia. Os bosques e as áreas de cultivo são propriedade comunitária e seu uso, acesso e aproveitamento, não predatórios, dependem de uma gestão coletiva do território. Os indígenas mantêm uma relação de sacralização com a terra, inexistente entre os colonizadores, e a produção é realizada em constante preocupação com a reposição dos bosques, conformado por um conjunto de elementos - terra, animais, frutos, água - que possuem, para eles, um sentido de articulação geral (PAZ, 2012).

A observação constante do clima, do comportamento dos animais, da relação entre os ciclos da lua, das águas e das plantações resulta no aguçado conhecimento que os indígenas possuem da natureza. Observa-se uma perspectiva holística de integração entre todos os entes que compõem o cosmos; ou seja, de "[...] totalidade espacio-temporal de la existencia, la vida com respecto a la totalidad" (WALSH, 2009, p. 216).

A interpretação ocidental de natureza - herdeira da tradição filosófica dualista e dicotômica de separação ontológica entre o mundo natural e o mundo social (DESCOLA, 2001; SANTOS, 2007; VIVEIROS DE CASTRO, 2002) - tornou-se o pressuposto que estrutura a epistemologia hegemônica e, através dela, os modos de identificação da natureza existentes entre os povos não ocidentais aparecem como curiosas representações da realidade, porém falsas: "[...] solo manipulaciones simbólicas de ese campo de fenómenos específico y circunscrito que nosotros llamamos naturaleza" (DESCOLA, 2001, p. 110). Porém, conforme evidenciado por antropólogos e intelectuais indígenas (DESCOLA, 2001; HUANACUNI, 2010; YAMPARA, 2008; VIVEIROS DE CASTRO, 2002; KOPENAWA e ALBERT, 2015), a 
interpretação hegemônica de natureza não deveria ser tomada como uma verdade absoluta, universal.

Entre vários grupos amazônicos, por exemplo, aquilo que o ocidente considera como natureza estaria permeado por características consideradas como exclusivamente humanas, tais como os processos de emoção, consciência e reflexão (VIVEIROS DE CASTRO, 2002). Em sua explicação sobre a crise ambiental global a partir da cosmologia do povo amazônico Yanomami, Davi Kopenawa (KOPENAWA e ALBERT, 2015) indaga se o ímpeto destruidor dos Brancos, os povos da mercadoria, não estaria relacionado ao fato de ignorarem outras dimensões da natureza já que, embora "engenhosos", os brancos "carecem muito de sabedoria" (2015, p.65). Segundo ele, os brancos desconhecem, por exemplo, a existência de seres que, embora invisíveis ou perceptíveis apenas durante os sonhos ou os rituais xamânicos, interferem no cotidiano dos indivíduos e das comunidades.

As formas utilitaristas de interpretação da natureza - a natureza como commodities, ou recursos naturais - subjacentes ao paradigma de desenvolvimento hegemônico são consideradas inconcebíveis para os indígenas. Segundo Davi Kopenawa, os habitantes da floresta não apreciam a ideia meio ambiente, que remeteria àquilo "[...] que resta da terra e da floresta feridas por suas máquinas. [...] de tudo o que eles destruíram até agora. Não gosto dessa palavra meio. A terra não deve ser recortada ao meio. (KOPENAWA e ALBERT, 2015, p.484)

Para além de relacionar-se com outros saberes e cosmovisões, a base produtiva dos indígenas, amazônicos ou andinos, assim como o de outros povos do Sul Global, em especial as civilizações agrárias (contemporâneas ou não), está orientada por uma perspectiva temporal cíclica. Conforme demonstram Paz (2012) e Tapia (2007), entre os indígenas do Tipnis as formas de produção e reprodução da vida social estão articuladas às mudanças estacionais, e os ciclos da natureza articulam todas as dimensões da vida social, política, econômica e ritualística. Cusicanqui (2010), ao refletir sobre a aposta de modernidade indígena com base em elementos cosmovisivos aimarás, afirma que os povos indígenas não concebem a história linearmente: "No hay 'post' ni 'pre' en una visión de la historia que no es lineal [...] que se mueve en ciclos y espirales. [...] el pasado-futuro están contenidos en el presente [...]" (2010, p. 54). 
Por outra parte, Tapia (2007) observa que "[...] uno de los rasgos de la modernidad es la sustitución de concepciones cíclicas o circulares del tiempo por nociones de tiempo histórico [...] lineales o progresivas" (TAPIA, 2007, p. 20-21). O autor explica que uma mudança significativa na percepção do tempo ocorreu na Europa, durante a Revolução Industrial, nos séculos XVII e XVIII, com o distanciamento cada vez mais radical entre os processos sociais e os ritmos das estações da natureza. Atrelado à necessidade de reduzir os tempos de rotação do capital e de produção de mercadorias, instaurou-se, naquele momento, um processo de aceleração temporal que consolidou a "flecha do tempo" capitalista, sempre posicionada em direção ao futuro, sempre lançada mais adiante, dirigida a modificar as condições da vida social sistematicamente.

O ideal de progresso perseguido pelos governos de todos os países - sejam eles do centro ou da periferia, do Norte ou do Sul, do Ocidente ou do Oriente, "progressistas" ou não - está orientado por esta flecha do tempo. É ela, também, que está por trás do do projeto da estrada que divide o Tipnis ao meio, impactando os seus ecossistemas e povos. É neste sentido que a concretização do projeto viário pode ser entendida como reflexo do avanço, sobre floresta e os povos que nela habitam, daquilo que Santos (2007) descreve como as monoculturas que estruturam a modernidade ocidental capitalista e colonial (para além do agressivo modelo agrícola da monocultura da soja).

III.c O avanço, sobre a floresta e seus povos, da monocultura da produtividade capitalista e da monocultura da temporalidade linear e progressiva

Partindo de Santos (2007), entende-se a modernidade ocidental capitalista como um paradigma fundamentado em diferentes monoculturas, entre as quais a monocultura da produtividade capitalista e a monocultura da temporalidade linear e progressiva. A primeira corresponde à transformação do critério de produtividade do crescimento econômico acelerado ad infinitum, próprio do modo de produção capitalista, como a lógica produtiva mais racional e, portanto, inquestionável. A segunda refere-se à cristalização da sequência temporal passado-presente-futuro, igualmente própria à cosmovisão moderna ocidental, como a única forma verdadeira de se perceber o tempo (SANTOS, 2007).

A cada uma destas monoculturas subjazem formas de legitimar e universalizar as experiências produzidas "do lado de cá" da linha abissal, o Norte 
Global, o lado colonial. Simultaneamente, está intrínseco à lógica monocultural da modernidade a "produção da não existência" dos povos e experiências produzidas "do lado de lá" da linha abissal, o lado do Sul Global. Estas formas de produção de não existência vão do silenciamento à marginalização, passando pelo extermínio. Conforme exposto na introdução, o direito e o conhecimento hegemônico são importantes ferramentas neste processo (SANTOS, 2007; SANTOS E MENEZES, 2010).

Santos (2007) e Santos e Menezes (2010) explicam que entre as formas de produção de não existência do Sul Global está a classificação das experiências não assentes nos critérios produtivos e temporais da modernidade capitalista como experiências primitivas, selvagens, atrasadas e subdesenvolvidas. O pensamento hegemônico converte, assim, simultaneidade em não contemporaneidade, criando um futuro único e homogêneo, onde a única possibilidade é seguir a lógica natural imposta pelas monoculturas da produtividade capitalista e da temporalidade linear. No mesmo sentido, Cusicanqui (2010, p. 59) reflete sobre a histórica negação da coetaneidade dos povos indígenas, a quem se outorga um status residual, preso a estereótipos. Conforme a autora, a própria noção de 'origem', embutida na ideia de povos originários, remete a um passado arcaico, estático, sem movimento.

As seguintes "palavras de um xamã Yanomami23" explicitam o esforço de Davi Kopenawa em fazer os brancos compreenderem a opção dos habitantes da floresta, que resistem à promessa moderna do progresso:

É por isso que eu gostaria que eles ouvissem minhas palavras [...]. Gostaria que, após tê-las compreendido, dissessem a si mesmos: 'os Yanomami são gente diferente de nós[...]. Agora entendemos o que eles pensam. [...] O pensamento deles segue caminhos outros que 0 da mercadoria. Eles querem viver como Ihes apraz. Assim seja! (2015, p.64-65)

Conforme discutido, a normativa plurinacional andina, formulada com a participação efetiva dos indígenas como sujeitos políticos ativos em seu processo de criação (SCHAVELZON, 2013) desafiaram a lógica monocultural hegemônica e ampliaram os caminhos para a autodeterminação dos povos indígenas. Mas o reforço do extrativismo como a base do programa desenvolvimentista levado a cabo pelo MAS

\footnotetext{
${ }^{23}$ Subtítulo do livro "A queda do céu", de Kopenawa e Albert (2015).
} 
no pós-constituinte, como no caso do Alianza País no Equador, destoou da normativa inovadora, desencadeando um intenso processo de desconstitucionalização. Ao sobrepor a lógica monocultural da modernidade ocidental às lógicas endógenas dos indígenas amazônicos (como as experiências produtivas comunitárias e temporais cíclicas), o projeto viário no Tipnis contribui para a "produção de não existência" dos yuracares, dos chimanes e dos mojeños trinitários, de suas práticas sociais e de seus saberes. Revela, assim, o avanço das monoculturas que estruturam a modernidade ocidental capitalista e colonial (Santos, 2007), para além da monocultura da soja, sinalizando o estabelecimento do progresso como horizonte civilizatório único, de todos os povos e nações, da China ao Tipnis.

\section{Considerações finais}

Através de um exercício reflexivo que foi do global ao local, o artigo buscou jogar novas luzes sobre o fenômeno complexo e multifacetado dos impactos socioambientais em territórios indígenas e biodiversos da América do Sul, nos primeiros 15 anos do século XXI. Deu-se destaque aos impactos causados pela intensificação do extrativismo, que recobrou fôlego como o eixo dos programas de desenvolvimento nacionais e regionais impulsionados pelos governos progressistas no contexto de alta demanda por commodities da China, em ascensão econômica no mesmo período.

Como síntese das disputas que se estabeleceram entre governos progressistas e organizações sociais, observou-se o conflito envolvendo o governo de Evo Morales e as organizações indígenas das terras baixas bolivianas em torno do projeto de construção da estrada no Tipnis, na Amazônia sul-boliviana. Assim como no Equador, os dilemas do neoextrativismo progressista - que articulou os benefícios econômicos gerados pela atividade produtiva à criação de eficazes políticas sociais, sem a diminuição dos impactos socioambientais - foram agravados pelo caráter vanguardista da normativa plurinacional que, orientada por um projeto de transformação social pós-extrativista e pós-abissal, legitimou o projeto políticocivilizatório do Vivir Bien e dos Direitos da Mãe Terra.

Como foi possível constatar, a infraestrutura viária no Tipnis atende, ainda que indiretamente, aos interesses de escoamento das commodities sul-americanas para o Pacífico, com destaque para a necessidade de envio da soja brasileira para a 
China. Além disso, explicita o avanço, sobre a floresta e seus povos, das monoculturas estruturantes da modernidade ocidental: a monocultura da produtividade capitalista e a monocultura da temporalidade linear e progressiva. Evidencia, assim, o reforço da cartografia abissal que o constitucionalismo plurinacional parecia desafiar.

A luta contra a construção da estrada no coração de seu território é, também, a resistência dos povos indígenas do Tipnis à ideia do progresso como futuro único e homogêneo que ela anuncia. É nesse sentido que a reflexão traz um olhar crítico sobre o modelo social que inspira o crescimento chinês e a voracidade da exploração de recursos naturais que o acompanha.

Não se trata de fazer coro à sinofobia que, em última instância, só serve para fortalecer os interesses dos EUA na região na atual guerra comercial entre os dois países, ou de ignorar a importância das parcerias Sul-Sul na construção de uma inserção internacional mais autônoma e menos subordinada por parte dos países da região. Tampouco trata-se de minimizar a importância dos governos progressistas na criação de políticas públicas que modificaram radicalmente a vida da população ou de responsabilizar os camponeses colonizadores do Tipnis - também explorados e subalternizados no interior desse sistema-mundo patriarcal/capitalista/colonial/moderno (GROSFOGUEL, 2010) - pelo reforço da lógica monocultural no Tipnis. Trata-se, não obstante, de dar visibilidade ao Buen Vivir/Vivir Bien e aos Direitos da Mãe Terra, que, em sintonia com outras propostas e lutas contra-hegemônicas provenientes do Sul Global, reforçam, a partir de um viés decolonial, a preocupação com a inviabilidade do modo de vida capitalista, orientado pelo grande paradigma do progresso, alcançar uma escala universal.

É importante aclarar que o estudo se restringiu aos primeiros 15 anos do século XXI e, por isso, não abarcou os novos fenômenos e novas transformações observadas nos últimos anos na América do Sul. Como o crescimento das inversões e investimentos chineses em projetos de infraestrutura na região nos últimos anos ou os novos desafios trazidos pela iniciativa Belt and Road que, anunciada em 2013 pelo líder chinês Xi Jinping, prevê a construção de grandes obras de infraestrutura para a integração da Euroásia e África, abrindo um novo momento na demanda por recursos naturais sul-americanos. Diante desses recentes processos, questiona-se se países da região seguirão reproduzindo o papel de exportadores de matéria prima com pouco ou nenhum valor agregado, em um novo contexto de ascensão do valor das 
commodities no mercado internacional (BRUCKMANN, 2018). Além disso, permanece a dúvida sobre se, caso aproveitem a oportunidade para condicionar as exportações a processos de transferência tecnológica e de industrialização, isso será realizado no marco do horizonte pós-extrativista e pós abissal como aquele proposto pelo Vivir Bien e pelos Direitos da Mãe Terra.

Tampouco foi abordada a radicalização do extrativismo subsequente à virada neoliberal, reacionária e conservadora, observada em diversos países da América do Sul, nos últimos anos ${ }^{24}$. Ela incluiu processos de destituições e golpes institucionais parlamentares, jurídicos e midiáticos seguidos da ascensão de governos alinhados com os interesses norte-americanos, o capitalismo financeiro e aquele setor que Abramovay (2010) define como a coalização do desmatamento: um conjunto de atores diversos, especializados na contestação e no desrespeito à legislação ambiental, na ocupação de terras indígenas ou públicas e na defesa de um crescimento econômico pautado pela exploração predatória. No novo contexto, o avanço das monoculturas anteriormente citadas e a subsequente produção da não existência dos povos e experiências "do lado de lá" da linha abissal acontecem de forma muito mais vigorosa, pois explicitamente amparada no extermínio físico, de fato, da floresta e dos povos que nela habitam.

\section{Referências Bibliográficas}

ABRAMOVAY, Ricardo. Desenvolvimento sustentável: qual a estratégia para o Brasil? Novos Estudos, n. 87, p. 97-113, jul. 2010.

ACOSTA, Alberto et al. Informe de la Comisión del Tribunal Internacional de Derechos de la Naturaleza sobre el caso TIPNIS - Bolivia. Quito, 2019.

; MARTÍNEZ, Esperanza (Org.). La naturaleza con derechos: de la filosofía a la política. Quito: Abya-Yala, 2011. p. 317-369.

El Buen Vivir: Sumak kawsay, una oportunidad para pensar otros mundos. Barcelona: Icária, 2013.

\footnotetext{
${ }^{24} \mathrm{~A}$ largada da virada reacionária neoliberal e conservadora que se observou na região nos últimos anos foi dada em 2009, no Paraguai, quando Fernando Lugo foi impedido de seguir o seu mandato. No Equador, depois de assumir o governo em 2017, Lenín Moreno rompeu com Rafael Correa (de quem foi vice), e afinou sua política com os setores de direita. No Chile, Sebastián Piñera está no poder desde 2010, Maurício Macri ficou na Argentina entre 2015 e 2019. No Brasil, Jair Bolsonaro passou a governar a partir de 2018 enquanto Iván Duque está na Colômbia desde 2018.
} 
BOLÍVIA. Constituição. Constituição Política do Estado Plurinacional da Bolívia, de 07 de fevereiro de 2009. Disponível em: <http://bolivia.infoleyes.com/shownorm.php?id=469>. Acesso em: 05 ago. 2011.

BRUCKMANN, Monica. América Latina y la nueva dinámica del sistema mundial. América Latina en Movimiento, v. 534, p. 1-5, 2018.

CASTRO-GÓMEZ, Santiago; GROSFOGUEL, Ramón. Giro decolonial, teoría crítica y pensamiento heterárquico. In: (orgs.). El giro decolonial. Reflexiones para una diversidad epistémica más allá del capitalismo global. Colombia: SiglodelHombre Editores, 2007, p. 9-25.

CID.CENTER FOR INTERNATIONAL DEVELOPMENT AT HARVARD UNIVERSITY. What did China Import from Brazil in 2016. In: Atlas of Economic Complexity. Cambridge (EUA): Harvard University, 2017. CID:2017, s/p.

CEPAL - Comissão Econômica para a América Latina e o Caribe. Panorama Social de América Latina. Santiago (Chile): CEPAL, 2014a

- Povos indígenas na América Latina: progressos da última década e desafios para garantir seus direitos. Santiago (Chile): CEPAL, 2014b.

CIMI. Conselho Indigenista Missionário. Relatório de violência contra os povos indígenas do Brasil. Brasília, CIMI: 2014.

COICA. Resolución COICA por la defensa del TIPNIS. 2017. Disponível em: $<$ https://coica.org.ec/resolucion-coica-por-la-defensa-del-territorio-indigena-parquenacional-isiboro-secure-tipnis/>. Acesso em: 31 out. 2019.

CPEMB - Central de Povos Étnicos Mojenhos do Beni. Pronunciamiento oficial, de 17 de julho de 2019. In: CEJIS. Indígenas del Tipnis exigen a la CIDH abrir el proceso de demanda para cancelar la construcción de la carretera. CEJIS, Noticias, 21 jul. 2020.

CUSICANQUI, Silvia Rivera. Ch'ixinakaxutxiwa. Una reflexión sobre prácticas y discursos descolonizadores. Buenos Aires: Retazos-Tinta Limón, 2010.

DESCOLA, Philippe.Construyendo naturalezas. Ecología simbólica y práctica social. In: DESCOLA,P. y PÁLSSON, G. (orgs.). Naturaleza y sociedad. Perspectivas antropológicas. México: Siglo XXI, 2001. p. 101-123.

FAO - Food and Agriculture Organization of the United Nations. FAOSTAT Statistics. Santiago (Chile): FAO, 2007.

. Voluntary guidelines for agro-environmental policies in Latin America and the Caribbean. Santiago (Chile): FAO, 2016. . O estado das florestas no mundo (Relatório). Santiago (Chile): FAO, 2018.

FRANK, Andre Gunder. El desarrollo del subdesarrollo. Madri: Zero, 1972. 

líderes indígenas de la Comunidad Andina. La Paz: Banco Mundial/Fundo Indígena, 2005. p. 97-124.

FURTADO, Celso. O mito do desenvolvimento econômico. Rio de Janeiro: Paz e Terra, 1974.

FUSCALDO, B. M. H. O constitucionalismo transformador da Bolívia e do Equador, ecológico e descolonizador. 250f. Tese - Doutorado em Ciências da Integração da América Latina, Universidade de São Paulo, São Paulo, 2016.

GROSFOGUEL, Ramón. Para descolonizar os estudos de economia política e os estudos pós-coloniais: transmodernidade, pensamento de fronteira e colonialidade global. In: SANTOS, Boaventura de S.; MENESES, Maria P. (Org.). Epistemologia do sul. São Paulo: Cortez, 2010. p. 455-491.

GUDYNAS, Eduardo. Diez tesis urgentes sobre el nuevo extractivismo: contextos y demandas bajo el progresismo sudamericano actual. In: SCHULDT, J. et al. Extractivismo, Política y Sociedad. Quito: CAAP/CLAES, 2009. p. 187-225.

HUANACUNI, Fernando. Paradigma occidental y paradigma indígena originario. América Latina em movimento, Quito, n. 2, p. 17-23, fev. 2010.

INPE - Instituto Nacional de Pesquisas Espaciais. Taxa anual do Projeto de Monitoramento do Desmatamento na Amazônia Legal por Satélite/PRODE. São José dos Campos: INPE, 2018.

KOPENAWA, Davi; ALBERT, Bruce. A queda do céu. Palavras de um xamã Yanomami. Tradução de Beatriz Perrone-Moisés. São Paulo: Companhia das Letras, 2015, 729 p.

LINERA, Álvaro García. Las tensiones creativas de la revolución: la quinta fase del proceso de cambio. La Paz: Luxemburgo, 2011.

. ONGs mentem e camuflam seu ativismo político e reacinário sob o mando de atividade não governamental, s/p. La Paz, 19 ago. 2015. Disponível em: $<$ http://mercosulcplp.blogspot.com.br/2015/08/alvaro-garcia-linera-respondesobre.html>. Acesso em 24 set.2015.

MACAS, Luis. SumakKawsay: La vida en plenitud. América Latina em Movimento: SumakKawsay, Recuperar o Sentido da Vida, Quito, n.2, p.14-17, fev. 2010.

MORAES, Renata Albuquerque de. Desenvolvimento e VivirBien: o caso do Território Indígena e Parque Nacional Isiboro Sécure (Bolívia). Dissertação (Mestrado em Ciências Sociais), Universidade de Brasília, Brasília, 2014.

OLIVEIRA, Oscar. Bolívia: Tipnis no meio do caminho. Entrevista a Tadeu Breda. Outras palavras, 3 out. 2011. 
PAZ, Sarela. Dos actores, dos modos de vida y un sector social en ascenso: los colonizadores. EI TIPNIS en el centro del interés global. La Paz: CEDIB - Centro de Documentación e Información de Bolívia, 2012. p. 1-10.

PNUD - Programa das Nações Unidas para o Desenvolvimento. Informe sobre o desenvolvimento humano. Nova York: PNUD, 2013.

PNUMA - Programa das Nações Unidas para o Meio Ambiente. Perspectivas del medio ambiente: América Latina y el Caribe. GEO ALC 3, 2010.

QUIJANO, Aníbal. Colonialidade do poder, eurocentrismo e América Latina. In: LANDER, Edgardo (Org.). A colonialidade do saber: eurocentrismo e ciências sociais perspectivas latino-americanas. Colección Sur-Sur. Buenos Aires: CLACSO, 2005. p. 227-278.

THE PEOPLE'S REPUBLIC OF CHINA. China to ensure food supply for $1.4 \mathrm{~b}$ people through own effort. Beijing, 22 de mai. de 2020. Disponível em: <http://english.www.gov.cn/premier/news/202005/22/content_WS5ec73398c6d0b3f0 e9498384.html>. Acesso em: 23 set. 2020.

ROCHA, Felipe F.; BIELSCHOWSKY, Ricardo. La búsqueda de China de recursos naturales en América. Revista de la CEPAL, n. 126, p. 10-20, dez. 2018.

SANTOS, Boaventura de Sousa. Para além do pensamento abissal: das linhas globais a uma ecologia dos saberes. Revista Crítica de Ciências Sociais, Coimbra, n. 78, p. 3-46, abr. 2007.

; MENESES, Maria Paula. Introdução. In: (Org.). Epistemologias do sul. São Paulo: Cortez: 2010. p. 9-21.

SCHAVELZON, Salvador. El nacimiento del Estado plurinacional de Bolivia: etnografía de una Asamblea Constituyente. La Paz: CLACSO; Plural Editores; CEJIS; IWGIA, 2013.

SERNAP - Servicio Nacional de Áreas Protegidas. Plan de Manejo del Territorio Indígena Parque Nacional Isiboro Sécure. La Paz: 2004.

SORUCO, Ximena. Apuntes para un Estado Plurinacional. Investigación para el fortalecimiento del Estado boliviano dentro del proceso de cambio. La Paz, Vice Presidencia del Estado, 2011.

TAPIA, Luis. El tempo histórico del desarrollo. In: WANDERLEY, F.(Org.). El desarrollo en cuestión: reflexiones desde América Latina. La Paz: CIDES; 2007. p. 19-27.

URQUIDI, Vivian F. O movimento cocaleiro na Bolivia. São Paulo: Hucitec, 2007.

VIVEIROS DE CASTRO, Eduardo. Perspectivismo e multinaturalismo na América Indígena. In: A inconstância da Alma Selvagem e outros ensaios de antropologia. São Paulo: Cosac \& Naif, 2002. p. 345-401. 
WALSH, Catherine. Interculturalidad, Estado, sociedad. Luchas (de) coloniales de nuestra época. Quito: UASB \& Abya-Yala, 2009.

YAMPARA, Simón. Empresa Ayllu ó Ayllu Qamaña? In: MEDINA, Javier (Org.). Suma Qamaña: la comprensión Indígena de la vida buena. La Paz: GPI, 2008. p. 137-147. 